\title{
Between the Diabolical and the Banal: Margalit on Humanism and Radical Evil
}

Nevo I*

Department of Philosophy, Ben-Gurion University, Israel

*Corresponding author: Isaac Nevo, Department of Philosophy, Ben-Gurion University, Beer Sheva, Israel, Email: yanni@bgu.ac.il

\section{Conceptual Paper}

Volume 3 Special Issue 1

Received Date: November 16, 2020

Published Date: December 15, 2020

DOI: $10.23880 /$ phij-16000S1-006

\section{Abstract}

In this paper, I wish to discuss the Israeli philosopher Avishai Margalit's revival of the notion of "radical evil" in his book On Compromise and Rotten Compromises (2010). Margalit, like Arendt in The Origins of Totalitarianism, sees the historical events of 20th century totalitarianism, specifically, Nazi cruelty and humiliation, as exemplifying an assault on morality itself (by attacking its enabling assumption of a shared humanity). Famously, Arendt withdrew, or complicated, her understanding of Nazi evil in her later notion, in Eichmann in Jerusalem, of the "banality" of evil. Contrary to both Arendt and Margalit, I shall argue that evil is neither radical nor banal. Arendt was right to withdraw the notion of radical evil, and Margalit does not make better sense of it, given the explanatory vacuity of attributing such motives to human agents. Yet, there is nothing banal in the conscious and intentional perpetration of evil, thoughtlessly or otherwise. The myriad ways through which the human pursuit of the good turn into monstrosities are historically, sociologically and psychologically deep and worthy of critical and theoretical reflection. Key words: Radical evil; banality of evil; totalitarianism; Nazism, Stalinism, humanism.

\section{Philosophical Background}

In this paper, I wish to discuss the Israeli philosopher Avishai Margalit's revival of the notion of "radical evil" in his book On Compromise and Rotten Compromises (2010). Originally a Kantian term, which refers in Religion within the Boundaries of Mere Reason [1], to the roots of evil in the human propensity to subvert the moral law, or to subordinate it to other incentives, Margalit, like Hannah Arendt in her Origins of Totalitarianism [2], invokes the term in a different, more substantive sense, referring to the principled undermining of morality itself in regimes of systematic cruelty and humiliation. In Kant's terminology, the term "radical" is used to suggest the root (radix) of the phenomenon under consideration, namely evil, and Kant is primarily interested in diagnosing the appearance of evil in the structure of human motivation (falling somewhere between the necessity of sensuous nature and the freedom of being determined by the moral law). Margalit, like Arendt before him (though he makes no mention of her), uses the term "radical" to suggest a difference of principle. In this usage, radical evil would be principled evil, or evil for its own sake, not merely (ordinary) evil as it is rooted in human motivation. Thus, while Kant denied the very possibility of making "evil qua evil" ([1], p. 84) into the incentive of one's maxim, describing that as "diabolical" (i.e., as not rooted in human possibilities), Margalit, like Arendt, sees the historical events of $20^{\text {th }}$ century totalitarianism, specifically, Nazi cruelty and humiliation, as exemplifying an assault on morality itself (by rejecting its enabling assumption of a shared humanity). Hence, radical evil (or evil perpetrated for its own sake) is understood as evil perpetrated for the sake of undermining morality, almost precisely what Kant saw as impossible.

Kant's problem is that evil can be accounted for neither in causal terms, which renders it unmotivated, nor as the ultimate motive, the incentive of a maxim, which would fail to rationalize the action falling under the maxim. Satan's cry in Milton's paradise Lost: “Evil, Be though my good!" (Paradise 


\section{Philosophy International Journal}

Lost bk. 4, l. 110 (1667)), as if evil itself could rationalize the action it leads to, is beyond the Kantian limits of humanly motivated action. It is, as Milton suggests, diabolical. Since evil is undeniable, or as Kant puts it (quoting from the New Testament (1 John 5:19), "the world lieth in evil," (ibid. p. 69 [6:18]) a question arises as to the place of evil, its roots, in human motivation, between the necessity of nature and autonomy of reason. As Kant puts it:

The depravity of human nature is therefore not to be named malice, if we take this word in the strict sense, namely as a disposition (a subjective principle of maxims) to incorporate evil qua evil for incentive into one's maxim (since this is diabolical) but should rather be named perversity of the heart, and this heart is then called evil because of what results. An evil heart can coexist with a will which in the abstract is good. (ibid. p. $84[6: 37])$.

For Kant, so it appears, the source of evil in human conduct is neither its sensuous nature, which is merely "animal," nor its capacity for reason, since reason cannot resist (or be "exonerated" of) the moral law. Rather it is in the "frailty of human nature," i.e., "in not being strong enough to comply with its adopted principles" (ibid. p. 84). In other words, Kant finds the roots of evil to lie in the "interface" between humanity's sensuous nature and its rationally willed moral law, namely, in the frailty which consists in knowing the moral law but failing to act purely upon its authority, thereby subordinating it to other incentives. These roots, however, do not involve anything like choosing evil for its own sake, or "an absolutely evil will" (ibid. p. 82) which Kant dismisses as "diabolical". Evil, for Kant is radical in the sense of being rooted in human frailty, in its "propensity" to subvert the moral law, but not in the substantive sense which makes evil into one's principle and aim. Rooted in the propensity to subordinate the moral law to non-moral (but not anti-moral) incentives, evil can be chosen knowingly and voluntarily, contrary to a longstanding philosophical tradition going back to Plato, but it cannot be chosen for its own sake. Kant's conception of radical evil does not leave room for such absolute evil.

Scholars [3,4] have noted that two senses of freedom play a role in this Kantian resolution regarding the place of evil. There is first the dominant Kantian sense of freedom as being determined by reason, or the moral law, which leaves no room for evil (since mere animal nature does not rise up to that level). Secondly, there is the sense of freedom as undetermined choice, which comes about in choosing to subordinate the moral law to other incentives. Kant sees that as a weakness, the frailty of human nature, but nevertheless a free choice which is constrained by our sensuous nature but not causally determined by it. Hence, we can choose between good and evil knowingly and voluntarily, though we cannot be motivated by evil, and cannot choose it for its own sake.

Writing in the aftermath of $20^{\text {th }}$ century horrors, Hannah Arendt writes of modern totalitarian evil as radical in a sense that assimilates it to what Kant saw as diabolical evil. Sensing the hellish conditions of the concentration camps, Arendt takes them to exemplify a hitherto unknown degree of evil, radical not only in its human roots but also in its principled dimensions, and attempts to account for it as the undermining of humanity, the making of human beings "superfluous" relative to the self-ascribed "omnipotence" of totalitarian systems. She, thus, assimilates Kant's "diabolical" evil to her notion of "radical" evil, making room for such principled evil within human affairs, while taking Kant to task for diminishing radical evil to just "perverted ill will," despite probably having a pre-conception of its ultimate dimensions. As we shall see, Margalit comes to a similar conclusion by an independent argument. Radical evil, for him, is the principle of undermining human morality by forcibly eliminating its presupposition, namely, that of a shared humanity, the fundamental equality of all human beings. For him, too, incorporating resistance to the presupposition of any morality into a motivating ideology is what radical evil, in a non-Kantian sense, amounts to. He thus comes very close to Arendt's interpretation of "evil qua evil" as evil in the name of eliminating humanity altogether.

In Origins, Arendt notices her difference from Kant in this regard (as does Margalit in his book), suggesting that Kant's identification of the roots of evil may nevertheless be seen as containing a glimpse of the possibility of principled evil as it has later been materialized in the history of totalitarianism. Her argument is as follows:

It is inherent in our entire philosophical tradition that we cannot conceive of a "radical evil," and this is true both for Christian theology, which conceded even to the devil himself a celestial origin, as well as for Kant, the only philosopher who, in the word he coined for it, at least must have suspected the existence of this evil though he immediately rationalized it in the concept of a "perverted ill will" that could be explained by comprehensible motives [2] (p. 459).

On this reading, Kant relegated principled evil to the realm of the diabolical while confining radical evil to humanly comprehensible motives, thereby "rationalizing" it. By contrast, Arendt finds in the history of totalitarianism a place between the human and the diabolical, namely, a place for principled evil within human affairs. As noted, that place is reserved to the historical appearance of a political system that is governed by a sense of omnipotence, for which "everything is possible" (ibid. p. 459), and which moves to eliminate any independent moral or human consideration. In this way, she both grounds herself on Kant's work and 


\section{Philosophy International Journal}

goes well beyond him to account for what appears to be an unprecedented (but on-going) historical reality. As she puts it:

Therefore, we actually have nothing to fall back on in order to understand a phenomenon that nevertheless confronts us with its overpowering reality and breaks down all the standards we know. There is only one thing that seems to be discernible: we may say that radical evil has emerged in connection with a system in which all men have become equally superfluous. (ibid. p. 459).

On this account, the perpetrators of radical evil, straddling the divide between the human and the diabolical, must themselves act as agents of the system, not on humanly comprehensible motives but rather as principled seekers of human superfluousness: "The manipulators of this system believe in their own superfluousness as much as in that of all others, and the totalitarian murderers are all the more dangerous because they do not care if they themselves are alive or dead..." (ibid. p. 459). Confronting Eichmann in Jerusalem some years later she came to realize that this was not true, and that what appeared as principled evil, seen from the lens of totalitarianism as a system, was merely banal humanly comprehensible -- when seen up close in the person of a perpetrator.

As noted, Arendt deployed a historicized model of evil-for-its-own-sake in her notion of rendering human being as such "superfluous." Totalitarianism is understood as a political system governed by a (delusory) principle of omnipotence, namely, the idea that "everything is possible," which leaves no room for (or no acknowledgement of) the humanity of independent subjects, capable of independent thought and (moral) judgment. As noted, Arendt withdrew the notion of radical evil, focusing instead on the "banality" of its perpetrator's motives. In a well-known letter to $G$. Scholem, who objected to her thesis of banality, she famously wrote: "it is indeed my opinion now that evil is never 'radical,' that it is only extreme, and that it possesses neither depth nor any demonic dimension" [7] (p. 251.). Some commentators [6] argued that Arendt's two conceptions of evil are mutually compatible, namely, that what she describes in Eichmann in Jerusalem (1963) as a "word-and-thought-defying banality" [7] (p. 252) in the person of an individual perpetrator (Eichmann) is already a form, or a consequence, of the radical evil appearing in the totalitarian system as a whole, in so far as the very humanity of that thoughtless perpetrator has already been entirely decimated. On this account, evil is radical in its systemic effects and banal in its individual manifestations, which leaves us with a notion of radical evil as a historically manifested pursuit of evil for its own sake, an institutional "will to evil" unmediated by any "guise of the good."
Unfortunately, the attempt to render compatible Arendt's two notions of evil - radical evil and the banality of evil -- is somewhat equivocal. Sometimes banality is understood in terms of petty motives that do not rise to the level of any principled aim. Eichmann, we are told, "was not Iago and not Macbeth, and nothing would have been farther from his mind than to determine with Richard III 'to prove a villain.' Except for an extraordinary diligence in looking out for his personal advancement, he had no motives at all" [7] (p. 287). Using the term in this sense, Arendt takes the banality of evil to replace her thesis of radical evil as principled evil exemplified in totalitarianism and its agents. In this light she claims that evil has no depth, i.e., no principle of its own, and that only the good has such depth. In another sense of the term, banality is identified as "thoughtlessness," in the specific sense of not being able to penetrate the moral meaning of one's actions. This second sense of banality is constructed from Arendt's rhetoric in speaking of "the fearsome, word-and-thoughtdefying banality of evil," as the ultimate lesson of "this long course in human wickedness." (ibid. p. 252). In the latter sense, the two notions of evil could be made compatible. Thoughtlessness, of the kind in question, could be seen as a manifestation, at the level of the individual perpetrator, of the superfluousness of humanity in the totalitarian system at large. It should however be noted that "thoughtlessness," in the requisite sense, does not point to what we would normally call "banal." In fact, thoughtlessness in this sense is far from an ordinary human phenomenon.

Contrary to both Arendt and Margalit, I shall argue that evil is neither radical nor banal. Arendt was right to withdraw the notion of radical evil, and Margalit does not make better sense of it, given the explanatory vacuity of attributing such motives to human agents. Yet, there is nothing banal in the conscious and intentional perpetration of evil, thoughtlessly or otherwise. Acting sub specie boni (under the guise of the good) remains constitutive of human agency, no matter how awful the outcomes are, so no radicalism of evil, in the principled sense, could be meaningfully attributed as a human motive, and no abstract agent -- a totalitarian system as a corporate body -- need be accounted for in terms of any such motives. But the absence of such inherently diabolical motives on the part of perpetrators, or the (moral) thoughtlessness incorporated into their practices, is by no means banal. The total breakdown of morality calls for both moral and psychological reflection. What we call evil are the myriad ways, social and psychological, in which the human pursuit of apparent goodness, through which human action is understood as such, can go awry, and result in monstrosities. Acting under "the guise of the good," people may nevertheless be led astray, and humanly understandable agents, including the worst perpetrators, may become responsible for the performance of unimaginable evil. As Kant puts it, "an evil 


\section{Philosophy International Journal}

heart can coexist with a will which in the abstract is good." (loc. cit. p. 84). This phenomenon need not be dismissed as banal, even while not rising to the level of the diabolical. It is, rather, the stuff of human history, politics, and psychology, which calls for careful analysis and empirical research.

\section{Margalit: An Assault on Morality Itself}

Avishai Margalit concluded his Tanner lectures (Stanford, 2005), which served as the basis for his 2010 book, with an appeal to "humanistic morality." Humanism, for him, is the belief in "shared humanity" as the basis of morality (in contradistinction to ethics which treats of more particularized social relations). His general idea is that humanistic morality should treat regimes of cruelty and humiliation, by which he means regimes of systematic dehumanization and crimes against humanity, in much the same way as religion treats sacrilege, or violations of holiness, i.e., by an absolute ban on any compromises with them. Margalit's book is an account of the legitimacy of political compromises, particularly compromises achieving peace even at the expense of justice, but it leaves out as inadmissible compromises with such regimes -- "rotten compromises" in his language -- as absolutely unacceptable. In this context, Margalit revives the doctrine of radical evil as it pertains to such regimes. According to him, regimes of systematic cruelty and humiliation constitute "an assault on humanity itself" [8] (p. 55), and thereby, on the presupposition of morality. More specifically, by rejecting the idea of a "shared humanity," the basic assumption of morality is undermined by such regimes, namely that there are duties one owes to another person simply in terms of her humanity. In particular, he finds such an assault on humanity, and on morality as such, in the Nazi ideology of racial domination, but also in slavery as practiced in the American south, in forms of colonialism such as Belgium's Leopold the II's genocidal practice in the Congo, and in similar racist-genocidal regimes, in contradistinction to other forms of totalitarianism, specifically, Soviet totalitarianism as practiced under Stalin. By denying the idea of a shared humanity, Nazi ideology, which is his main example, constituted an assault on morality itself and was thus a prime example of radical evil. Referring to the Munich pact, Margalit explains:

A pact with Hitler was a pact with radical evil, evil as an assault on morality itself. Not recognizing Hitler as radically evil was a moral failure on top of a bad error of political judgment.

[Nazism] stood for radical evil. By that I mean not just committing evil but trying to eradicate the very idea of morality - by actively rejecting the premise on which morality is predicated, namely, our shared humanity (ibid. p. 22).
In terms of our previous account, Margalit uses the term "radical evil" in the non-Kantian, principled sense. Radical evil, for him, is not just evil as it is rooted in human nature, but evil committed for the sake of eradicating morality. On his account, that is what the Nazis attempted to do, and it comes close to what Kant had described as Malice, namely, making evil as such, in the form of eradicating the moral law, the incentive of one's maxim. For Margalit, the idea of a "shared humanity" is the basis of morality, and on this view "evil qua evil" is reinterpreted as evil for the sake of eradicating morality by rejecting the premise on which it is predicated. Like Arendt in Origins, Margalit takes modern history to exemplify the possibility which Kant had rejected. His analysis of that possibility is more philosophical than Arendt's, resting not on an attribution of self-delusional "omnipotence" as the basis for making humans "superfluous," but rather on its overt racism as incompatible with the presupposition of morality.

While applauding Margalit's conception of humanism, I wish to take issue with his notion of radical evil, which to my mind oversteps the boundaries of humanism and introduces an unnecessary cleavage within the idea of humanity. In rejecting the distinction between evil and radical evil, I wish to endorse a more comprehensive humanism, a humanism which applies to even the worst imaginable perpetrators, including Hitler and his band of murderers, and to the understanding of their actions and motives. The moral point here is that we have to view even the worst perpetrators as human beings, rather than motivationally incomprehensible demons, if we are to be able to view human beings, generally, even those close to us in our own societies, as potentially capable of the worst, and so demanding of our closest scrutiny.

"Humanism" is a vague term, but one of its components is the conception of humanity as a whole, including its worst perpetrators of evil, as exemplifying basic conditions of rationality in both action and cognition, and as being understandable, or interpretable, on the basis of comprehensible beliefs and desires, i.e., reasons. This is the sense of humanism expressed in the phrase "nothing human is foreign to me," including, of course, all degrees and manners of human evil, which the humanist seeks to understand on the basis of its reasons and motives. On this view, evil is certainly possible to the worst degree, but it is not metaphysically basic; its source is always some failure in the pursuit of a comprehensible motive. In so far as we understand human beings rationally, i.e., in terms of their reasons for action, we cannot but view them as acting sub species boni, namely, "under the guise of the good," otherwise, our conception of them as human is eclipsed. Hence, moral humanism, namely, the view that morality presupposes a conception of a shared 


\section{Philosophy International Journal}

human dignity, requires a "conceptual" humanism as well, i.e., the conception of human beings as being essentially understandable, or interpretable, in terms of reasons, in terms of beliefs and desires, and so also in terms of the good they desire. Attributing "evil qua evil" as a human desire (an incentive of a maxim, in Kant's terminology) does not rationalize the behavior so interpreted, and is consequently not reasonably attributable to them. We understand evil by understanding the mechanisms leading from understandable motives to judgments and actions we condemn.

The concept of radical evil undermines this humanist conception. It raises the possibility that humanity is not unified under such basic rationality conditions, but has also much darker, and not rationally explicable, sources of motivation and action. The concept of radical evil, in the substantive sense shared by Margalit and Arendt (but not Kant), requires an attribution of a fundamental motive for evil, or for undermining human morality, which is not derived from a more basic desire, conscious or unconscious, for some motivating good. To account for it we would have to answer the question of what it might be to desire what is bad for its own sake, without any further motive which might render the desire in question intelligible in terms of the interest it serves. In Margalit's terminology, we would have to ask ourselves what it might mean to aim at the elimination of human morality as such, rather than aiming at the replacement of one normative system by another. The question is whether a desire for evil as such, or the elimination of human morality, is coherently attributable as the underlying motive of even the most horrifying perpetrators, and does it supply a better understanding, or any at all, of their actions? Another question is whether there might be a moral price to be paid for seeking an understanding along these lines, a price in terms of demonizing the perpetrators beyond recognition as human agents, and also of prematurely forgiving other perpetrators who fall short of such radical and ultimate evil (e.g., Stalin as compared with Hitler).

Before moving to discuss Margalit's argument, let me point out that there are two senses of the term "radical evil" that appear in his book. In one of these senses, the broader, Margalit ties radical evil with systematic cruelty and humiliation in a way that renders such cruelty and humiliation sufficient for radical evil. Systematic cruelty and humiliation constitute an assault on morality itself and are in this way radically evil. In Margalit's language:

A Rotten compromise that establishes or maintains an inhuman regime of cruelty and humiliation is an assault on morality itself, and that is what makes it radically evil (ibid. p. 55).

In this wide sense the term, radical evil can serve to describe many political regimes in which systematic cruelty and humiliation are prevalent, including no doubt the Stalinist regime in the Soviet Union. In a narrower sense of the term, radical evil involves further necessary conditions, in particular, radical evil requires an assault on the very existence of a common humanity, not merely the practice of systematic cruelty and humiliation. In this sense of the term, Margalit absolves Stalin's regime from the charge of radical evil. Thus, for example, he says (regarding Churchill's decision to join forces with Stalin against Hitler):

...when Churchill made his judgment, Stalin had already committed his worst, whereas Hitler was far from having done his worst yet. And yet I believe Churchill was right, not because Stalin's worst was not up to Hitler's worst -than-worst, but because Hitler's evil was radical evil, undermining morality itself. Stalin's monstrous evil was different, and Churchill correctly sensed the difference when he said that Hitler stands for one thing: 'racial domination'. (ibid. pp.178-9).

Margalit, of course, does not absolve Stalin of horrific cruelty and humiliation, but he refrains from attributing radical evil to him, and distinguishes in light of this concept between Soviet and Nazi totalitarianism. It follows that in one sense systematic cruelty and humiliation are still not sufficient for radical evil, and further requirements are necessary, such as alluded to by the phrase "racial domination" attributed to Churchill. In what follows, I shall confine myself to discussing the narrower sense of the term, ignoring its broader use. I believe Margalit's distinction between admissible and inadmissible political compromises can be made in terms of the broader concept of cruelty and humiliation, without dragging radical evil into the mix, but I shall not argue that point. Rather, I shall examine Margalit's argument for radical evil in the narrower sense, arguing that it is insufficient to justify his use of the term, even in relation to the Nazi case. I shall conclude by returning to Hannah Arendt's shift from radicalism to banality in her understanding of evil, arguing, against both Arendt and Margalit, that evil is neither radical nor banal, but rather a whole slew of human mechanism, some cognitive some social, through which understandable human motives turn into monstrous behavior.

Margalit's main argument for the radical nature of Nazi evil is as follows:

The idea is that the main premise of morality is shared humanity. Nazi racism, both in doctrine and in practice, was a conscious attack on the idea of shared humanity, and hence on the very possibility of morality itself... (ibid. p. 189).

To this, Margalit adds the following claim:

When it comes to Nazism there is no room for morality. ... Future humanity in Hitler's fantasy is not humanity: the master race replaces the idea of humanity. This is 


\section{Philosophy International Journal}

radical evil, if anything is. ... (ibid. p. 197).

The main argument, so it appears, is a derivation of "an attack on the very possibility of morality itself," as a fitting description of Nazism, from "a conscious attack on the idea of shared humanity," as such a description. The additional premise of the argument, explicitly stated, is that shared humanity is a "premise" standing at the foundation of morality. Thus, a conscious attack on the foundation is also an attack on the whole edifice.

In short, the argument has two premises jointly supporting the conclusion: (1) Nazism constituted a conscious attack on (the idea of) shared humanity; (2) (the idea of) shared humanity is the basis for the possibility of morality; therefore, Nazism constituted a (conscious?) attack on basis for the possibility of morality. In that respect it deserves to be seen as radical evil in the substantive, or principled, sense of the term, not merely the commission of immorality but doing so for the purpose of undermining morality as such. The argument, it should be said, is open to a rather standard critique. If its conclusion is that Nazism constituted a conscious attack on (the possibility of) morality, then its validity is open to question due to the intentionality of the adverb "conscious." A conscious attack on (the idea of) shared humanity is not necessarily a conscious attack on (the possibility of) morality, even if, in practice, the one attack leads to the other. The argument is valid, if the intentional characterization of "conscious" does not carry over to the conclusion. If $\mathrm{B}$ depends on $\mathrm{A}$, then a conscious attack on A is also an attack on B (whether or not it is so consciously). But there is room for doubt whether it makes sense, in an argument for radical evil, to remove intentionality from its description. By definition, radical evil is supposed to be evil perpetrated for its own sake. Evil for the sake of evil, or as presently understood, for the sake of eradicating morality, not for some other purpose. Indeed, Margalit emphasizes the doctrinal character of Nazi evil, namely, its being deliberate in its pursuit of immorality, while absolving Stalinist Communism from this charge, due to its being directed, at least in doctrine, towards a universal and positive aim of equality and the elimination of exploitation. It follows that Margalit's conclusion is not validly supported by its premises. We have to take into account the possibility that the Nazis did indeed aspire to eliminate any human solidarity, and permanently divide humanity into superior and inferior races, and yet that they did so on the basis of some normative consideration, distorted though it might be. Margalit points to the Nazi conceptions of Hygiene, filth, parasitism and degeneracy, which served the Nazis in justifying their policies, but he does not view these concepts as relevant for a moral discussion. In this, however, he misses one of the possible keys to understanding the Nazi phenomenon in point of its normative dimensions, i.e., in point of being a special case, monstrous though it might be, of the human aspiration for rectitude and justification. At this crucial point, Margalit prefers judgment: "this is radical evil, if anything is" (loc. cit.) to understanding, or to the more humanist judgment: "nothing human is foreign to me," since judging evil to be radical does not lead to any understanding of it in terms of humanly understandable motivations.

In addition, both premises of the argument could be questioned. Here I shall do so only briefly. The first premise attributes to the Nazis the motive of eradicating morality by consciously attacking shared humanity. But there are questionable empirical assumptions in this account which have been disputed by "functionalist" historians and sociologists in their disputes against "intentionalist" accounts regarding Nazi atrocities. This is not the place to review these historical debates, but Margalit's assumption regarding Nazi ideology as a conscious assault on humanity and morality - a rational choice, motivated as with Milton's Satan, by evil in place of the good -- appears to side with the intentionalist camp on what is an empirical matter. But is that a plausible account? Racial hatred dehumanizes its victims, and the Nazis clearly acted out such dehumanization in scapegoating the Jews. But whether it is a dehumanizing ideology - a conscious assault on shared humanity --that motivates the hatred, or is it rather the other way around, the conscious ideology being merely a projection of social and psychological conditions, is to my mind an open question. The second premise is also highly questionable. Here, too, I can only be brief, but the philosophical claim according to which "the main premise of morality is shared humanity" clearly admits of alternatives. Kant's second formulation of the categorical imperative in terms of treating humanity as such as an end in itself rather than merely a means, is clearly a fundamental moral intuition, but whether it is the premise upon which morality is predicated is less than certain. Other bases for morality, in terms of virtue or utility, have to be excluded before that claim could be made to stick.

Margalit offers relevant considerations in this regard. Drawing a distinction between thick and thin human relations, where thick human relations are particularized relations obtaining between members of specific families, clans, or nations, while thin human relations are those obtaining between human beings solely in point of being human, he goes on to distinguish ethics from morality along these lines. Ethics is said to regulate thick social relations while morality regulates thin human relations. Ethics, in other words, deals with the communal good, while morality is narrower in scope and deals with what human beings owe each other solely in terms of being human, i.e., in terms of what they all share as such, their "shared humanity." Margalit uses this distinction to account for tribal societies. A tribal society is one which maintains ethical relations among its 


\section{Philosophy International Journal}

members while being entirely immoral in its attitudes to strangers. Indeed, according to Margalit "Aryan Nazi Germany was an ethical society with regard to its fellow Germans, and a deeply immoral society with regard to humanity at large." (ibid. p.122). But while it is not particularly problematic to conceive of Nazi Germany as such a tribal society, it should be noted that this account is markedly different from the account of it in terms of radical evil. On the tribal society account, the Nazis are to be understood as committing their horrors with the aim of establishing their own ethics and view of the good, rather than following, like Satan, evil in place of the good. Indeed, Margalit admits, in a footnote, that he does not "consider relations to be ethical unless they pass a threshold of morality," (ibid. p. 205 (ch. 5, ft. 2)), so even a tribal society cannot be conceived as being so radically evil as to attempt the complete eradication of morality.

Thus, the characterization of Aryan Nazi Germany as a tribal society, fundamentally immoral in its "external" relations but "internally" ethical, calls into question Margalit's further characterization of the Nazi regime as radically evil. It turns out that, in its Aryan Nazi incarnation, radical evil is not a form of evil that is devoid of ethics even as it constitutes an assault on morality. Evil for the sake of eliminating morality can now be understood as compatible with some internal ethics, or some conception of the communal good. But this move raises a question about the point of using that term (in its substantive, non-Kantian, sense). A radical evil which is not understood as the pursuit of evil qua evil, but merely as the rejection of shared human morality for the sake of implementing a distorted ethics, or a communal conception of the good, is a lot less radical than previously imagined. Here, again, what we have is a form of evil that's rooted in a conception of the good, however distorted. It is not clear that this notion of radical evil would serve for a relevant distinction between Hitler's regime and Stalin's, who also acted in the name of a distorted conception of the good to annihilate millions of people.

By way of an example, let us consider Himmler's well known speech to SS officers on October 1943, in Posen. The following are some of his most chilling words:

To have gone through this [the extermination of the Jews] and at the same time to have remained decent, that has made us hard. This is a chapter of glory in our history which has never been written, and which never shall be written, since we know how hard it would be for us if we still had the Jews, living among us as secret saboteurs, agitators, and slander-mongers. Among us now, in every city - during the bombing raids, with the suffering and deprivations of the war. We would probably already be in the same situation as in 1916 and 1917 if we still had the Jews in the body of the German people.
We had the moral right, we had the duty to our own people, to kill these people who wanted to kill us. But we don't have the right to enrich ourselves even with one fur, one watch, one mark, one cigarette, or anything else. Just because we eradicated a bacillus doesn't mean we want to be infected by the bacillus ourselves....

In general, however, we can say that we have carried out this most difficult task out of love for our own people. And we have suffered no harm to our inner self, our soul, our character in so doing ${ }^{1}$.

It is hard to think of words more horrifying than these, where the evil of extermination is so consciously and deliberately embraced. Nevertheless, the justificatory intent of the speech is much closer to Margalit's characterization of tribalism, namely communal ethics without moral constraint, than to radical evil as the pursuit of evil for its own sake, or its pursuit for the sake of eliminating morality. Himmler justifies the extermination to his officers in terms that allude to the national good as he perceives it, namely "to kill the people who wanted to kill us," as they have allegedly done in 1917, and to do this with "decency" and "moral right," and without being "infected" by the vice of greed attributed to the victims. The anti-Semitic stereotype is clearly in evidence in these deranged beliefs, as is the complete incapacity to view the victims as human beings. Still, despite his conscious and deliberate advocacy of evil, and his obvious desire to keep it secret, nothing would have been farther from Himmler's mind than to "justify" the extermination, or intend it, as the elimination of morality as such. Indeed, the conscious and intentional pursuit of evil is not yet the pursuit of evil qua evil. Pace Plato, the former is clearly possible, not just as weakness of the will, or Kantian "frailty," but also as the pursuit of what is perceived as the lesser evil in the name of some conception of the good. Pathological though it may be, Himmler's speech falls into that pattern. But the pursuit of evil qua evil, or for the purpose of eliminating morality, does not appear to be any part of his motive.

In this context, one is reminded of Eichmann's claim in his trial to have been a follower of Kant's in his conception of duty. In her discussion of the issue, Arendt points out (Arendt, 1963: pp. 135-7) that although Eichmann recognized that the extermination orders could not be conceived as Kantian duty, and that in accepting his role in the extermination apparatus he was not his own master, there still remained a Kantian residue in his attitudes to the effect that duty, even in the form of the Führer's orders, must not just be obeyed but also internalized as one's own will - acting from duty and not just in accordance with duty. Once the Führer's will came

1 https://alphahistory.com/holocaust/himmlers-speech-at-posen-1943 


\section{Philosophy International Journal}

to replace the categorical imperative as the basis of duty, the result had been a case of acting from (perceived) duty but not in accordance with (moral) duty. Both Himmler's appeal to "decency" and Eichmann's appeal to "duty" are cases of complete moral blindness due to the insertion of a pathological dehumanization into their motives and their normative self-understanding. The consequences were horrific, and they call for a psychological explanation. But there is no intellectual or moral advantage in interpreting these actions and motivations as directed towards evil as such, or the elimination of any morality, rather than a normative view that got off the rails, and so as still part of our common human world.

Let me now return to the basic question regarding the possibility of radical evil. As Arendt noted, the philosophical tradition tended to reject notions of radical evil, in the substantive, or principled sense of the term, as incoherent. We should, however, ask whether or not the atrocities of the $20^{\text {th }}$ century may require a correction in this regard, as both Arendt and Margalit seem to believe, and at what intellectual and perhaps moral price. Does the concept of radical evil add any new possibilities of understanding or condemnation? I wish to argue that such additional possibilities of understanding that the concept seems to provide call for a close examination, for it is likely that what these possibilities amount to is rather a lack of understanding, or more precisely, a refusal, or rejection, of understanding on moral grounds. The desire and pursuit of evil for its own sake, or the elimination of morality as such, cannot be accounted for as a comprehensible motive and attributing such a desire as a reason for the perpetrators' actions does not advance our understanding of them. No intellectual advantage is offered by the attribution of a desire to an agent, the abstract content of which - evil for the sake of evil - does not rationalize any action to which it is supposed to lead in terms of its expected good. Satan's hope, in Milton, for evil to become his guiding "good," suggests a humanly incoherent principle of evil, alongside the good, not an account of evil in terms of understandable goods.

Similarly, the additional possibilities of condemnation that the attribution of radical evil supposedly offers us are deceptive. The need to distinguish evil not just from the good, but also, on the other side, from something even worse, possibly inhuman, can disfigure our judgment scale. Indeed, the concept of radical evil contains a dimension of unwarranted exculpation, or legitimation, both with respect to "regular" evil, which is suddenly pushed back to the middle of the judgmental scale, no longer the polar opposite of the morally good, but somewhere in between the good and the radically evil, and also with respect to the "radical" case, which appears to be so absolute and inhuman as to be left outside any regular context of condemnation and judgment.
Generally speaking, understanding is not forgiveness; intelligible condemnation requires understanding too, and we are quite capable of condemning immoral or evil actions while fully understanding their motives. But in a more selective context, where some evil deeds are declared radical, while others are taken to be understandable in terms of their positive motives, understanding does appear to be a kind of forgiveness, a granting of "normality" to some perpetrators, which is denied to others whose wrongdoing may not be all that different in its dimensions of horror. In this way we are tempted to grant a certain legitimation to Stalin, or others, by contrasting them with Hitler's absolute evil. We may, of course, still judge and condemn them, but it does appear as if we have granted them a legitimacy they have not earned.

Margalit raises this issue in his comparison between Hitlerism and Stalinism. On the face of it, he argues, there isn't much of a moral difference between mass-killing Jews as parasites, on the basis of racial theory, and mass-killing the bourgeoisie, or "kulaks," on the basis of class theory. In both cases, the term "parasites" expresses a horrendous form of dehumanization. In the nineteen thirties millions of Ukrainians were deliberately starved to death as part of soviet collectivization, and what makes this atrocity any less horrible, morally speaking, than the extermination of millions of Jews? What is it that makes Nazi extermination more radical? The following is Marglit's argument:

What makes genocide a horrendous crime, however, above and beyond horrific indiscriminate mass killing, is that genocide is a manifestation of dismembering the idea of shared humanity. By targeting a specific category of human beings as creatures that do not deserve to live, genocide removes this category from human kind (ibid. p. 182).

But what is the nature of this judgment? Why does the extermination of those who belong a specific national category constitute not just a greater evil, but also a different case in principle from "merely" the murder of millions without the further extermination of the "human category" to which they belong? Genocide is definitely its own category of crime, but it is not a metaphysical category involving humanly incomprehensible, or demonic, motives. Margalit's answer is that the latter case of mass murder could still be seen as an attempt to redesign humanity under some universal principle, however misapplied, whereas the former (Nazi) case is one where any conception of a common humanity is destroyed. But there is something problematic in this account, which places the collective category above the individual lives that were destroyed, and finds its destruction to be radically evil whereas the extermination of the individuals without regard to the collective category is seen as a lesser category of evil, one that is more understandable under universal principles, and so as not "radical." Here we find ourselves trapped into 
an unwarranted granting of normalcy. It now appears that killing millions by starvation is not at the end of the scale of human depravity, just because no collective category had been destroyed, and so it can be understood In light of universal principles.

Hence, the addition of principled evil to the repertoire of human motivation adds little by way of making contemporary forms of evil more intelligible, nor do we gain much in terms of our resources for condemning the perpetrators. By the same token, the rejection of radical evil does not amount to accepting what Arendt called the banality of evil, though we saw that Arendt does use the latter concept to reject the former. It does not follow that the perpetrators of evil are nothing but thoughtless bureaucrats without motives or psychological complexities that could be deciphered. The banality thesis diminishes the possibilities of human evil, and ties them solely with modern social conditions such as bureaucratization, atomization, or Mechanization. But the efficient train officer need not be taken to exhaust the range of evil possibilities, and a complex psychological dimension need not be excluded. While not being Shakespearean characters, Eichmann and his ilk need not be conceived as "thoughtless," or psychologically and intellectually empty, as Arendt seems to suggest. Evil is neither radical nor banal; rather it is the wide variety of human possibilities, all highly intriguing, of moving from understandable motives and positive conceptions of the good all the way to monstrous, sadistic, totalitarian and merciless actions. These possibilities are as wide as human society, as far ranging as human history, and as deep as human psychology. In all these ways, it is part of human life; not a "different planet," nor an incomprehensible appearance of anything "diabolical."

\section{References}

1. Kant I (1996) [1793] Religion within the Boundaries of mere Reason. In: Allen W Wood, George Di Giovanni (Eds.), Religion and Rational Theology. Cambridge University Press, Cambridge.

2. Arendt $\mathrm{H}$ (1951) The Origins of Totalitarianism. Meridian Books, New York.

3. Fackenheim EL (1954) Kant and Radical Evil. University of Toronto Quarterly 23(4): 339-353.

4. Bernstein RJ (2002) Radical Evi. Polity Press in association with Blackwell Publishers, Oxford UK \& Melden MA.

5. Arendt H (1978) The Jew as Pariah. Ron H Feldman (Ed.), The Grove Press, New York.

6. Bernstein RJ (1996) Hannah Arendt and the Jewish Question. The M.I.T Press, Cambridge, MA.

7. Arendt $\mathrm{H}$ (1963) Eichmann in Jerusalem. The Viking Press, New York.

8. Margalit A (2010) On Compromise and Rotten Compromises. Princeton \& Oxford: Princeton University Press.

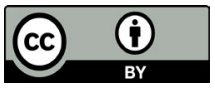

